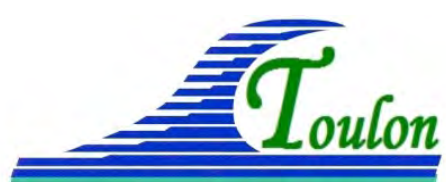

XIV èmes Journées Nationales Génie Côtier - Génie Civil Toulon, 29 juin au $1^{\text {er }}$ juillet 2016

DOI:10.5150/jngcgc.2016.069 (C) Editions Paralia CFL

disponible en ligne - http://www.paralia.fr - available online

\title{
Investigation of polluted marine dredged sediment in North Sumatera, Indonesia
}

\author{
Ernesto SILITONGA ${ }^{1}$
}

\author{
1. State University of Medan, Jalan Willem Iskandar Pasar V Medan Estate \\ Medan 20221 North Sumatera, Indonesia. ernestosilitonga@yahoo.fr
}

\begin{abstract}
:
Efficient and environmentally reutilization of dredged waste material in Indonesia calls for a multi disciplinary effort. That is why, the scientific, technological and economic information required to make an optimal choice among dredged waste because material disposal sites is now urgently needed in Indonesia. The reuse of dredged sediment as a new material for the construction of foundation and base layers for roads is one of the solution. An effective method for reusing dredged waste materials as a new material in road construction is illustrated in this paper using pozzolanic binders (fly ash and silica fume). The main goal of this study is to describe the behavioural aspect of dredged sediment stabilized with pozzolanic binders (silica fume and fly ash) as a binder for a use in road pavement work. The addition of pozzolanic binders as a partial cement replacement is realized due to its engineering, economic and ecological benefits. The first step realized to identify the mechanical and chemical characteristics of the pozzolanic binders and the dredged sediments. The second stage consists of identifying mechanical behaviour of dredged sediment with addition of different percentage of pozzolanic binders. Finally, the chemical identification of dredged sediments with various percentage of binders (with or without pozzolanic binders) were performed, compared and analysed. The results show that the addition of pozzolanic binders in mixture improves mechanical characteristics and reduce the pollutants content.
\end{abstract}

Keywords: Dredged sediments, Silica fume, Fly ash, Unconfined compressive strength, Leaching Test.

\section{Introduction}

The reutilization of waste materials such as dredged sediment in road construction is one of the main applications. Information about the physical, chemical and biological processes that need to be considered in particular dredged waste material situation are linked together by means of predictive techniques. Various alternative existing treatment methods to reuse dredged sediments have been investigated in European countries (BOUTOUIL, 1998). Previous research on the use of raw fine sediments in road construction has shown that treatment by hydraulic binders and the potential use of dredged sediments as a new material in road construction has been realized by several researchers (ZENTAR et al., 2008; KAMALI et al., 2008). Previous studies concerning 


\section{Thème 6 - Gestion durable des zones littorales et estuariennes}

the potential use of dredged sediments as a material filler and in road construction was performed in the laboratory by several researchers (SILITONGA, 2010; KAMALI et al., 2008). Since fly ash is by itself considered a waste, adding fly ash to treat contaminated dredged sediment would be a cost-effective method of disposing of it (SILITONGA et al., 2009 \& 2010). It would provide economic benefits by reducing disposal costs and mitigating possible negative environmental effects, originating in either the fly ash or the solid waste, through proper engineering control, which is why in this study we tried to replace fly ash as alternative binders. It has been known that the addition of silica fume, fly ash improve the geotechnical properties, due to the pozzolanic reaction and its role as a micro-filler, to achieve effectiveness of fly ash on soil stabilization work. The re-utilization of dredged sediment provides economic benefits by reducing disposal costs and mitigating possible negative environmental effects, originating in either the fly ash or the solid waste, through proper engineering control, which is why in this study the researcher tried to replace silica fume as alternative binders. It has been known that the addition of silica fume improves the geotechnical properties, due to the pozzolanic reaction and its role as a micro-filler. To achieve effectiveness of silica fume on soil stabilization work, some researchers added a small amount of hydraulic binders such as lime and cement. The need for a large amount of hydraulic binder makes the use of raw dredged sediments unlikely from an economic point of view. Trying to make a more productive use of silica fume would have considerable environmental benefits, reducing air and water pollution.

\section{Material}

The marine dredged sediments used in this study were taken from the port of Belawan, North Sumatera Indonesia. Figure 1 shows the location of Belawan port.
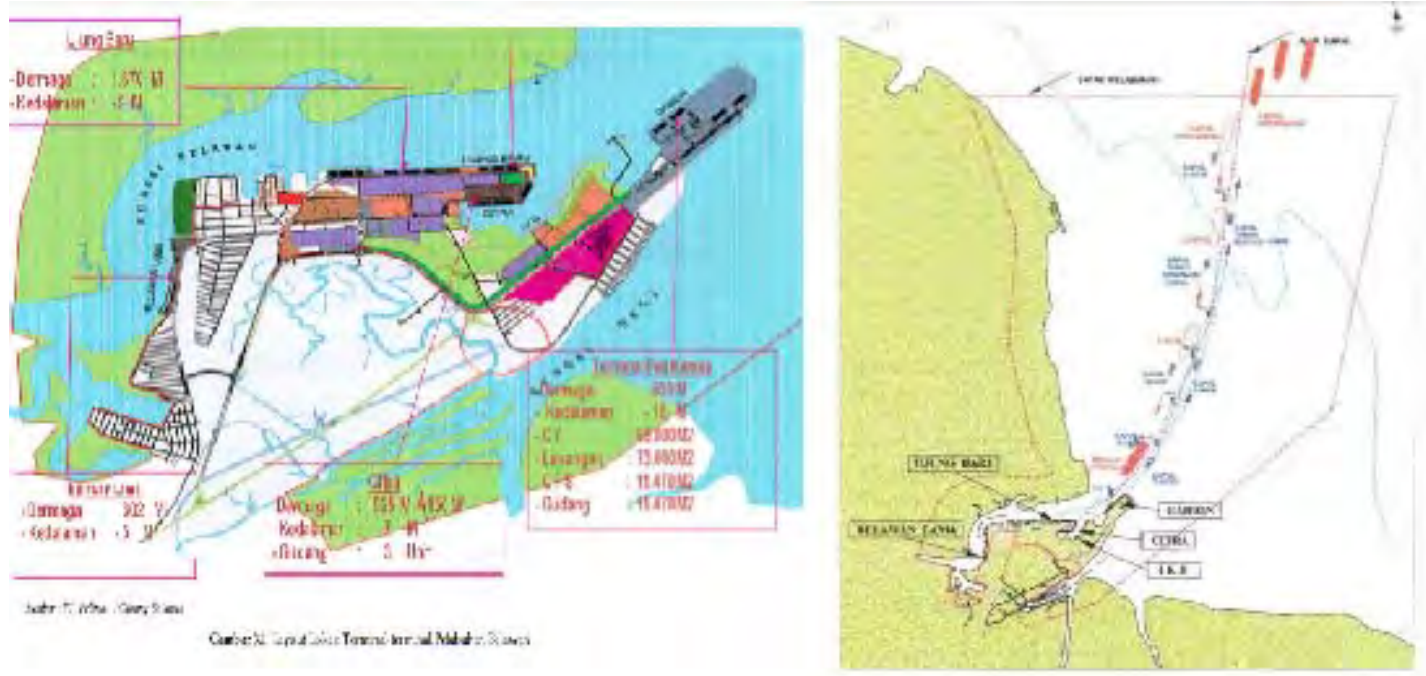

Figure 1. Map of Belawan port. 


\section{XIV èmes Journées Nationales Génie Côtier - Génie Civil \\ Toulon, 29 juin au $1^{\text {er }}$ juillet 2016}

Access to the Malacca Strait linked by shipping channel along $\pm 13.5 \mathrm{~km}$ with a width of $100 \mathrm{~m}$ and a depth of 8.5 mwls to 10:00 mwls, while harbor pool depth is 6.0 to 11.5 mlws. Belawan port is located $03^{\circ} 47^{\prime}$ North latitude and $98^{\circ} 42^{\prime}$ East longitude, in North side bordered by rivers Belawan, and Deli river in the South side.

The sediments used in this study were taken by Trailing Suction Hopper Dredger. The dredged sediments were taken from six different locations (PoB A-1, PoB A-2, PoB A3 , PoB A-4, PoB A-5 and PoB A-6). The sediments are dredged from the sea-bed at a depth of about $22 \mathrm{~m}$.

\subsection{Particle size distribution}

\subsubsection{Dredged sediments}

Different methods have been used to describe the particle size distribution of powders of various types and sizes up to now. In this study, a Beckman Coulter LS 1332 SW laser diffractometer was used to determine the particle size distribution (PSD) of the dredged sediments. Another advantage of using binder with fines particles such as silica fume, is its particles size distribution. It has been known that particles size distribution control the water demand and workability of the mixture. Previous study have shown that calcium content, the size distribution and the shape of the particle of fly ash were the most important parameters acting on the strength development rate of the mixture (JATURAPITAKKUL et al., 1999). Study by BINICI et al. (2007) showed that the specimen with a better fineness and a narrower particle size distribution had the highest compressive strength, sulphate resistance compared the others specimens. Besides provides the strength development rate, the fineness particle size of the binder such as silica fume (SILITONGA, 2010), a narrower particle size distribution could present a high compressive strength, sulphate resistance (JOSHI \& LOHTIA, 1997). The influence of the finer particle size of silica produces more reactive pozzolanic reaction because smaller particle size of silica fume with a higher surface area and glassy phase content also improved the pozzolanic reaction.

There are two types of silica fume used in this study (SF1 and SF2) as shown in figure 1 , all binders utilized have different particle size distribution from the point of view of particle diameter most representative; silica fume type $1(7.24 \mu \mathrm{m})$ has finer particles than type 2 (SF2). From this result, it can be expected that silica fume 2 content will provide more strength in mechanical test. The previous experiment by Silitonga (SILITONGA, 2010) showed that the compressive strength tends to reduce as the mean particle size increases for all curing ages. The reduction of the strength might be caused by coarse particles of binder tends to reduce the ability of packing effect of binder and disturbing pozzolanic reaction to enhance mechanical characteristics. 
Thème 6 - Gestion durable des zones littorales et estuariennes

Table 1. Characteristic diameters of dredged sediment cement, fly ash and silica fume

\begin{tabular}{lllllll}
\hline Particle size & $\mathbf{D 1 0}(\boldsymbol{\mu m})$ & $\mathbf{D 5 0}(\boldsymbol{\mu m})$ & $\mathbf{D 9 0}(\boldsymbol{\mu m})$ & $\begin{array}{l}\text { Clay (\%) } \\
<\mathbf{2} \boldsymbol{\mu m}\end{array}$ & $\begin{array}{l}\text { Silts (\%) } \\
\mathbf{2 - 6 3} \boldsymbol{\mu m}\end{array}$ & $\begin{array}{l}\text { Sand (\%) } \\
\mathbf{6 3} \boldsymbol{\mu m}\end{array}$ \\
\hline Dredged sediment & 168.3 & 46.1 & 3.922 & 3.96 & 61.81 & 34.23 \\
Cement & 730.1 & 34.24 & 0.61 & 13.97 & 56.02 & 30.01 \\
Silica fume 1 & 9.53 & 11.15 & 10.2 & 31.85 & 47.22 & 20.93 \\
Silica fume 2 & 3.89 & 7.24 & 8.5 & 40.43 & 48.56 & 11.01 \\
\hline
\end{tabular}

\subsubsection{Pozzolanic binders}

As shown in table 2, we can notice the differences in chemical analysis between silica fume type 1 (SF1) and type 2 (SF2) but it can be seen that SF1 and SF2 were both characterized by a high content of $\mathrm{SiO}_{2}$ (75-92\%), the difference between SF1 and SF2 is the amount of the mineral in each silica fume.

It is well known that high content of $\mathrm{SiO}_{2}$ and its finest particles constitute the most important factor to improve the physical properties of the mixture. (compressive strength, tensile strength, etc.). Silitonga on his research noticed that one type silica fume which possesses higher $\mathrm{SiO}_{2}$ content, produces higher resistance on Unconfined Compressive Strength Test (SILITONGA, 2010). On the other hand fly ash contains more $\mathrm{CaO}$, which is very important to help pozzolanic reaction. According to this result, we can expect that SF1 will be more reactive than FS2 as a pozzolanic binder.

Table 2 Result of Chemical Test between SF1 and SF2

\begin{tabular}{|c|c|c|}
\hline Parameter & Silica fume 1 & Silica fume 2 \\
\hline Colour & Light Silver & Dark Silver \\
\hline $\mathrm{SiO}_{2}$ & $90-92$ & $75-85$ \\
\hline $\mathrm{Fe}_{2} \mathrm{O}_{3}$ & $1,5-2$ & $1-2$ \\
\hline $\mathrm{AI}_{2} \mathrm{O}_{3}$ & 1 & 1 \\
\hline $\mathrm{CaO}$ & $0,5-1$ & $0,5-1$ \\
\hline $\mathrm{MgO}$ & $1-1,5$ & $1-2$ \\
\hline $\mathrm{Na}_{2} \mathrm{O}$ & $0,5-1$ & $0.2-0.8$ \\
\hline $\mathrm{K}_{2} \mathrm{O}$ & $1-1,3$ & $0.5-1.0$ \\
\hline C & $0,5-1$ & $0,3-1$ \\
\hline Free CaO (\%) & $<1$ & $<1-2$ \\
\hline $\mathrm{SO}_{3}(\%)$ & $<1$ & $0,5-1$ \\
\hline $\mathrm{Cl}(\%)$ & $<0,2$ & $<0,3$ \\
\hline Specific area $\left(\mathrm{m}^{2} / \mathrm{g}\right)$ & $18-25$ & $20-25$ \\
\hline
\end{tabular}

\section{Methods and Results}

\subsection{Preparation}

The dredged sediment, oven-dried for 5 days at $60^{\circ} \mathrm{C}$ was pulverized to $2 \mathrm{~mm}$ sieve size, it was initially mixed with determined quantities of fly ash, silica fume, lime and 


\section{XIV ${ }^{\text {èmes }}$ Journées Nationales Génie Côtier - Génie Civil \\ Toulon, 29 juin au $1^{\text {er }}$ juillet 2016}

cement as a binder, in a dry state and subsequently mixed with water by a mechanical mixer with a speed of $150 \mathrm{rd} / \mathrm{min}$ for a period of approximately 8 minutes. After mixing the samples were prepared with the static compaction method, at the optimum moisture content and maximum density determined by Proctor test. Cylindrical specimens ( $\varnothing=40 \mathrm{~mm}, \mathrm{~h}=80 \mathrm{~mm}$ ) were used for unconfined compressive strength testing. The compressive strength is determined using a $10 \mathrm{kN}$ capacity automatic compression machine according to NF EN 196-1 (NF, 1995) on a simple speed cross-head moving machine at a speed of $1 \mathrm{~mm} / \mathrm{s}$. The samples were pushed out from the mould directly after completion of the compaction and were stored in the curing room until testing at 7 , 14, 28, 60, 90, 180 and 360 days.

\subsection{Mix design}

In order to determine the effect of pozzolanic binders on the mixtures performances, several compositions were realized. The different formulas in this experiment are given in table 3.

Table 3. Mixtures composition performed

\begin{tabular}{llllll}
\hline Name & Symbol & FS1 (\%) & FS2 (\%) & Lime (\%) & Cement (\%) \\
\hline Silica fume Type 1 & SF-1A & 3 & - & 2 & 2 \\
& SF-1B & 6 & - & 2 & 2 \\
\hline \multirow{2}{*}{ Silica fume Type 2 } & SF-2A & - & 3 & 2 & 2 \\
& SF-2B & - & 6 & 2 & 2 \\
\hline Cement & CEM-1 & - & & - & 5 \\
\hline
\end{tabular}

The goal of manufacturing SF-1B and SF-2B, was to compare the influence of pozzolanic binders if the amount increases two times. The amount of $2 \%$ of cement was the common amount that normally used in the road construction field, due to this reason, the sample CEM-1 was realized. CEM-1 and CEM-2 were realized to identify the behaviour of the mixtures without any pozzolanic binders.

\subsection{Unconfined compressive strength (U.C.S)}

In order to determine the effect of binders used in this study, one of the most commonly parameter in road construction, Unconfined Compressive Strength (UCS) test was realized. The result of UCS test was shown in figure 2 .

As shown in figure 2, we divided all result to 2 different ages, (a) early-medium age (728 days) and (b) long term age, all the mixtures were tested at age of 7, 14, 28, 60, 90, 180 and 360 days. This method is realized to help to identify the improvement pattern of UCS. The hydration of cement is well known contribute a rapid strength gain of the samples. This theory shown at UCS test result at early age (7-14 days). As shown in 
table 4 up until the curing age of 28 days, samples with high cement content (CEM-1 and CEM2) have the highest UCS values. At Long term (90-360 days) curing age sample with cement content do not show any significant UCS values improvement.

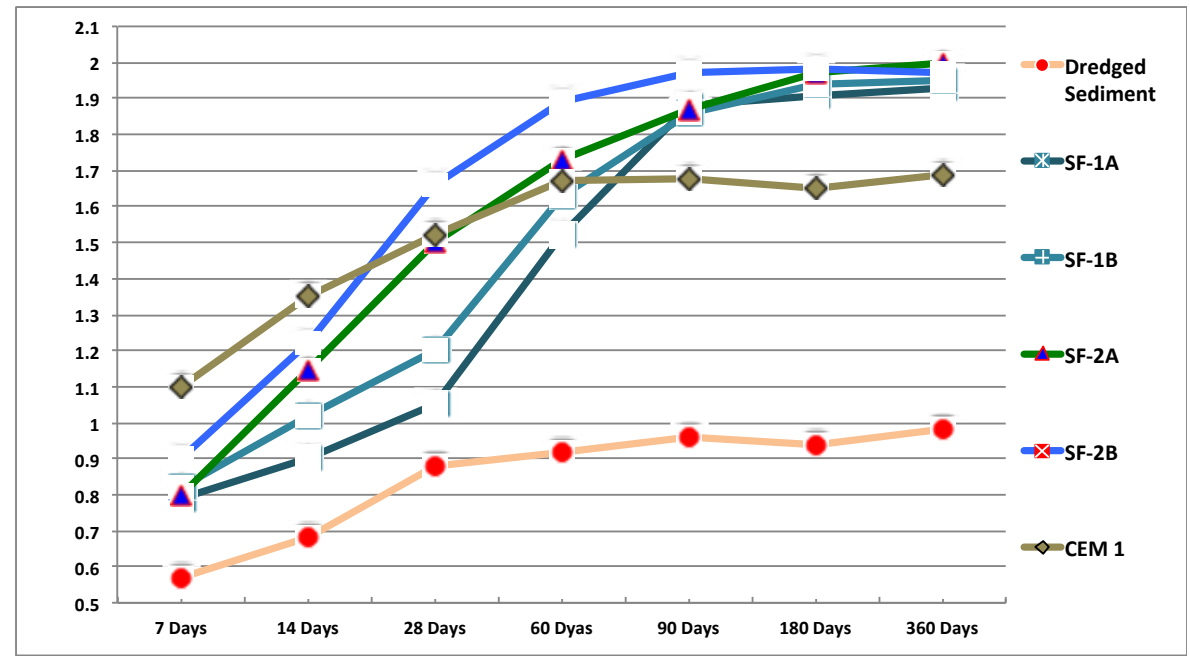

Figure 2. Results of Unconfined Compressive Strength (UCS) test.

Table 4. Results of Unconfined Compressive Strength (UCS) test

\begin{tabular}{llllllll}
\hline Name & 7 Days & 14 Days & 28 Days & 60 Days & 90 Days & $\mathbf{1 8 0}$ Days & 360 Days \\
\hline Dredged sediment & 0.57 & 0.68 & 0.88 & 0.92 & 0.96 & 0.94 & 0.98 \\
SF-1A & 0.79 & 0.9 & 1.05 & 1.52 & 1.88 & 1.91 & 1.93 \\
SF-1B & 0.82 & 1.02 & 1.2 & 1.63 & 1.86 & 1.94 & 1.95 \\
SF-2A & 0.8 & 1.15 & 1.5 & 1.73 & 1.87 & 1.97 & 2 \\
SF-2B & 0.9 & 1.22 & 1.66 & 1.89 & 1.97 & 1.98 & 1.97 \\
CEM 1 & 1.1 & 1.35 & 1.52 & 1.67 & 1.68 & 1.65 & 1.69 \\
\hline
\end{tabular}

Samples with silica fume content show an important increase values especially sample with $6 \%$ content of silica fume (SF-2). At this age (7 days) the effect of the finest particle size of silica fume plays an important role to improve the UCS, help to generate heat, which accelerates the cementitious and pozzolanic reactions. Normally the hydration of silica fume start to contributes strength gain at 14 days curing ages.

The performance between type 1 and type 2 silica fume (SF1 and SF2) does not show very large difference. Although as we can see the type 2 silica fume (SF2) with 6\% of silica shows a significant improvement on UCS performance from early age (7 days) up to long term age (360 days). These results show that the type 2, with 6\% silica fume (SF2) used in this study help lime to provides $\mathrm{Ca}(\mathrm{OH})_{2}$, required for the pozzolanic reaction to occurs and produces $\mathrm{C}-\mathrm{A}-\mathrm{H}$ and $\mathrm{C}-\mathrm{S}-\mathrm{H}$ which are very important factor to the strength gain. From the result we can notice that the ideal amount of silica fume to make difference is $6 \%$. Samples with $3 \%$ of silica fume did not show a significant 


\section{XIV ${ }^{\text {èmes }}$ Journées Nationales Génie Côtier - Génie Civil \\ Toulon, 29 juin au $1^{\text {er }}$ juillet 2016}

difference on UCS performance to identify the difference of particle size distribution or chemical properties of each silica fume.

\subsection{Leaching test (Chemical properties)}

In order to identify the content of the pollutants in dredged sediments, leaching test was performed for sediments from all locations (see table 5). The dredged sediments were taken from six different locations (PoB-1, PoB-2, PoB-3, PoB-4, PoB-5 and PoB-6).

Table 5. Results of leaching test

\begin{tabular}{lllllll}
\hline Element & PoB-1 & PoB-2 & PoB-3 & PoB-4 & PoB-5 & PoB-6 \\
\hline Nickel, $\mathrm{Ni}$ & 0.09 & 0.17 & 0.04 & 0.11 & 0.05 & 0.05 \\
Cadmium, Cd & 1.85 & 0.86 & 0.29 & 1.96 & 1.68 & 2.07 \\
Chromium, Cr & 0.22 & 0.08 & 0.98 & 0.27 & 0.51 & 0.38 \\
Copper, $\mathrm{Cu}$ & 0.71 & 0.242 & 0.37 & 0.29 & 0.6 & 0.41 \\
Lead, $\mathrm{Pb}$ & 0.67 & 0.9 & 0.1 & 0.88 & 0.07 & 0.45 \\
Zinc, $\mathrm{Zn}$ & 24.6 & 19.2 & 35.0 & 32.8 & 41.1 & 29.5 \\
Mercury, $\mathrm{Hg}$ & 0.008 & 0.002 & 0.011 & 0.005 & 0.011 & 0.001 \\
Arsenic, $\mathrm{As}$ & 0.19 & 0.08 & 0.38 & 0.095 & 0.08 & 0.24 \\
\hline
\end{tabular}

The results in table 5 show that from all locations in which the sediments were taken, sample from PoB-5 is the most contaminated among others, according to its quantity of heavy metal contaminants, especially Zinc (Zn) and Copper (Cu).

The dredged sediment was planned for land application. However, as the land applied dredged sediment is subjected to drying and oxidation, transformations in the chemical forms of heavy metals may affect their mobility and bioavailability, and phytotoxicity may occur by the application of dredged sediment on land. Therefore, it is necessary to assess the environmental risk of the dredged sediment before its land application. This leaching test was realized according to French standard NF X 31-210 (1998), which refers to the solution containing the solubilized elements during the test, which are performed on the analytical characterization.

The leaching test is divided in three steps according to the chemical environment applied in the test: (a) the static leaching, we identify the leached elements in solution after presenting sample to the aqueous solution, (b) semi dynamic leaching, where test applied with a regular renewal of the leaching solution, (c) the dynamic leaching test in which the leaching solution is continuously renewed. This leaching test is a simulation to identify the mixture reaction to aggressive chemical environment.

Each country in Europe already establish their own reference values for waste landfills, but in order to unify the same acceptable reference values for waste landfills, the European Council established reference values (No. 2003/33/EC) for the acceptance criteria in inert, non-hazardous and hazardous waste landfills. These values relate to the 
elements contained in the leachate and not in the raw material. The reference values are shown in table 6. Because of the lack of reference values especially for dredged sediment in Indonesia, the author decided to utilize reference values of European Council. In order to classify the dredged sediment of Belawan, these reference values used to identify/ classify the amount of pollutants in sediment of Port of Belawan.

Table 6. Reference values for dredged sediments

\begin{tabular}{lll}
\hline Inert waste & Non-hazardous waste & Hazardous waste \\
\hline 0,4 & 10 & 40 \\
0,04 & 1 & 5 \\
2 & 50 & 100 \\
0,01 & 0,2 & 2 \\
0,5 & 10 & 50 \\
4 & 50 & 200 \\
0,01 & 0,2 & 2 \\
0,5 & 2 & 25 \\
\hline
\end{tabular}

In this paper, only leaching test result for Cadmium (Cd) and Copper (Cu) were presented and analysed. As shown in figure 3, leaching test for dredged sediment categorize in non-hazardous waste $(1-5 \mathrm{mg} / \mathrm{kg})$. As shown in figure 3 , the effect of binders utilized reduces the concentration of Cadmium and Copper. Although only sample with $6 \%$ of silica fume (SF-2) show a significant reduction in Cadmium concentration, after treatment with $6 \%$ of silica fume the concentration reduces from category Non hazardous waste to Inert waste. This concentration element reduction is surely due to the presence of silica fume. Apparently even though the sample shows a diminution of Cd concentration but the amount of 3\% SF was not sufficient to produce remarkable reduction of $\mathrm{Cd}$ concentration. Samples with fly ash content equally show a reduction on Cd concentration, although it is not as remarkable as silica fume, but we could see the effect of fly ash to reduce the Cd concentration. Probably because the samples were examined at 60 days of curing age, if the leaching test had been realized at 90,180 or 360 days, there is possibilities that the samples with fly ash would have shown a important effect on reducing Heavy Metal element concentration. At long term curing age (>90 days) the pozzolanic reaction of fly ash already reacts completely. On the other hand, sample with only cement content show a minor reduction of $\mathrm{Cd}$ concentration compared to initial $\mathrm{Cd}$ concentration. The increase of percentage of cement (from $4 \%$ to $8 \%$ ) does not give remarkable reduction, from this result we can consider that cement as a binder is not effective enough to reduce the heavy metal concentration. 


\section{XIV ${ }^{\text {èmes }}$ Journées Nationales Génie Côtier - Génie Civil \\ Toulon, 29 juin au $1^{\text {er }}$ juillet 2016}

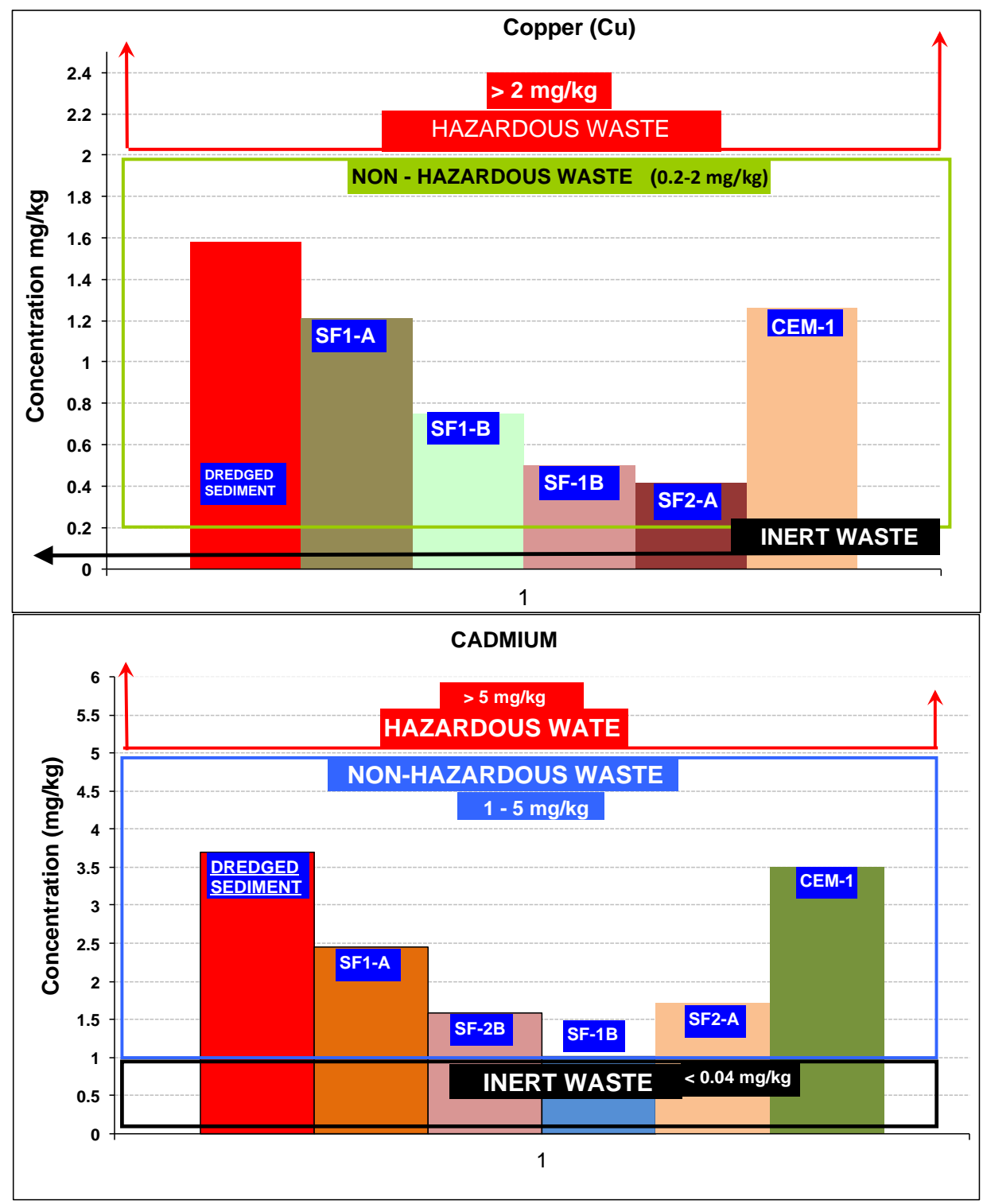

Figure 3. Cadmium and Copper value relate to the elements contained in the leachate.

\section{Conclusion}

The main goal of this experiment is to identify the effect of binders especially pozzolanic binder such silica fume on the strength behaviour, its capacity to reduce the pollutants. The improvement in mechanical properties such as unconfined compressive strength values were investigated. Sediment-cement mixture, sediment-lime mixture and sediment-silica fume mixture were prepared and compacted at the optimum water content. Unconfined compressive strength tests were then performed on these mixtures in normal conditions and in extreme conditions. The UCS values gained by specimen treated silica fume type 1 (SF1) were continuously increased up to 100 days, although the percentage of increase is not as high as that of specimens treated with silica fume type 2 (SF2), for the specimens treated by cement, the increase of UCS value strength 
almost stop after 60 days. The research has shown that, from the comparison of different various specimens, the sediment stabilized with silica fume-lime-cement have the most potential values than the others to offer an alternative for stabilization of dredged sediments. From the leaching test, the presence of silica fume in mixture proved effective to reduce the amount of pollutant in dredged sediment, thus the dredged sediment could be reused as a new material. The sample with fly ash content requires more time (>90 days) to maximally react and reduce the pollutants.

\section{References}

BINICI H., AKSOGAN O., CAGATAY I.H., TOKYAY M., EMSEN E. (2007). The effect of particle size distribution on the properties of blended cements incorporating GGBFS and natural pozzolan. Powder Technology, Vol. 177(3), pp 140-147. http://dx.doi.org/10.1016/j.powtec.2007.03.033

BOUTOUIL M. (1998). Traitement de vases de dragage par solidification/stabilisation à base de ciment et additifs. Thèse de l'Université du Havre. 279 p.

JATURAPITAKKUL C., KIATTIKOMOL K., SONGPIRIYAKIJ S. (1999). A study of strength activity index of ground coarse fly ash with Portland cement. ScienceAsia, Vol. 25, pp 223-229. http://dx.doi.org/10.2306/scienceasia1513-1874.1999.25.223

JOSHI R.C., LOHTIA R.P. (1997). Fly Ash in concrete, production, properties, and uses. Gordon and Breach Science Publisher, Vol. 2, pp 27-29.

KAMALI S., BERNARD F., ABRIAK N.E., DEGRUGILLIERS P. (2008). Marine dredged sediments materials resource for road construction. Waste Management, Vol. 28(5), pp 919-228. http://dx.doi.org/10.1016/j.wasman.2007.03.027

SILITONGA E. (2010). Valorisation des sédiments marins contaminés par solidification/stabilisation à base de liants hydrauliques et de fumée de silice. Thèse de doctorat, Université de Caen, France, 160 p.

SILITONGA E., LEVACHER D., MEZAZIGH S. (2009). Effects of the use of fly ash as a binder on the mechanical behaviour of treated dredged sediments. Environmental Technology, Vol 30(8), pp 799-807. http://dx.doi.org/10.1080/09593330902990089

SILITONGA E., LEVACHER. D., MEZAZIGH S. (2010). Utilization of fly ash for stabilization of marine dredged sediments. European Journal of Environmental and Civil Engineering, Vol. 14(2), pp 253-265. http://dx.doi.org/10.1080/19648189.2010.9693216

ZENTAR R., DUBOIS V., ABRIAK N.E. (2008). Mechanical behaviour and environmental impacts of a test road built with marine dredged sediments. Resources, Conservation and Recycling, Vol. 52, pp 947-954. http://dx.doi.org/10.1016/j.resconrec.2008.02.002 